\title{
プラズマ溶融処理した非金属廃棄物のマイクロ波加熱装置を 用いる迅速溶解法
}

原賀 智子 ${ }^{\circledR 1}$, 亀尾 裕 $^{1}$, 中島 幹雄 $^{1}$

\author{
Rapid Dissolution Techniques with Microwave Heating Devices \\ for Solidified Products Made from Non-Metallic Wastes \\ by Plasma Melting
}

\author{
Tomoko HARAGA $^{1}$, Yutaka KAMEO ${ }^{1}$ and Mikio NAKASHIMA ${ }^{1}$ \\ ${ }^{1}$ Japan Atomic Energy Agency, 2-4, Shirakata-Shirane Tokai-mura, Naka-gun, Ibaraki 319-1195 \\ (Received 9 August 2005, Accepted 15 October 2005)
}

\begin{abstract}
A relatively large quantity of sample solutions have to be prepared for the radiochemical analysis of solidified products yielded by a plasma melting treatment of non-metallic radioactive wastes. In order to dissolve a sample of solidified products rapidly, a dissolution method with microwave heating devices was applied. In a conventional method involving only external heating with various mixtures of acids $\left(\mathrm{HNO}_{3}, \mathrm{HF}, \mathrm{HClO}_{4}\right.$ and $\left.\mathrm{H}_{2} \mathrm{SO}_{4}\right)$, a $0.1 \mathrm{~g}$ amount of the sample was dissolved with difficulty. However, upon applying the microwave-assisted dissolution method, a $1 \mathrm{~g}$ amount of the sample was completely dissolved in a shorter time. Thereby the time for dissolution procedures was shortened to less than one-tenth. The present dissolution method was successfully applied to blast furnace slag as a reference material to determine the main elements with good precision.
\end{abstract}

Keywords : microwave heating; rapid dissolution techniques; non-metallic wastes; solidified products; plasma melting.

\section{1 緒言}

プラズマ溶融処理は, 廃棄物の減容・安定化のために, 一般廃棄物, 有害廃棄物, 放射性廃棄物等の処理方法とし て利用されている. 日本原子力研究開発機構 (原子力機構) では, 研究所から発生する低レベル放射性廃裹物のうち, コンクリートやレンガなどの不燃性廃棄物, 塩化ビニルな どの難燃性廃裹物, 可燃物を焼却した灰等をプラズマ加熱 により溶融し，ガラス状の化学的に安定な溶融固化体に成 形してから廃棄体として埋設処分することを計画してい $ろ^{1)}$. 原子力機構において非金属廃棄物をプラズマ溶融し て製作される溶融固化体は, $\mathrm{SiO}_{2}, \mathrm{Al}_{2} \mathrm{O}_{3}, \mathrm{CaO}$ 等を主成 分とするガラス状の物質で, 化学的安定性に優れ, 高い放

${ }^{1}$ 日本原子力研究開発機構: 319-1195 茨城県那珂郡東海村白方 白根 2-4
射性核種閉じ込め性を有している2). 溶融固化体を安全に処分するためには，固化体中に含ま れる放射性核種の種類と量を把握する必要がある. 放射化 学分析を行うためには, 前処理として試料を溶液化するこ とが必要であるが, ガラス状の物質である溶融固化体を溶 解する作業には長時間を要する。また, 研究所等から発生 する廃棄物の場合, 安全評価上考慮すべき核種の種類が多 く，その濃度も様々であるため ${ }^{3)}$, 分析を行うためには比 較的多量の試料が必要であり，1〜10 g 程度の試料を溶液 化しなければならない ${ }^{4)}$. 一般的な化学成分分析では 0.01 $\sim 0.1 \mathrm{~g}$ 程度の試料で十分であるのと比較すると，分析に 必要な試料量が多いため, 溶融固化体試料に対する迅速な 溶解方法を検討する必要がある。

ガラスや耐火物などの難溶解性物質の溶解法としては, 硝酸やフッ化水素酸, 硫酸等を用いた外部加熱による酸分 


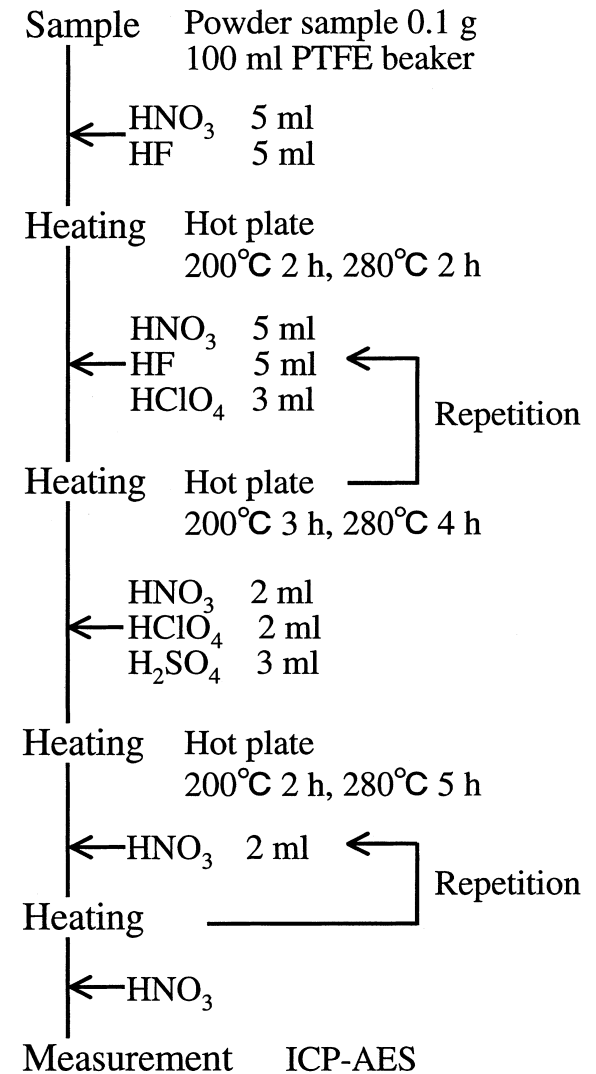

Fig. 1 Dissolution procedure by external heating for a solidified product yielded by plasma melting treatment

解法 ${ }^{5) \sim 7)}$ が報告されているが，この方法は通常，分解にか かる時間が長い. また, 水酸化ナトリウムや炭酸ナトリウ ム等を用いたアルカリ融解法 ${ }^{7}$ は, 酸分解が困難な難溶解 性試料によく用いられているが，溶解液の塩濃度が高くな り, 測定装置への負担が大きい。最近では，酸分解法にお いても効率的に溶解を行うために, 密閉加圧容器を使用し た溶解法 ${ }^{778)}$ や, 熱効率の良いマイクロ波加熱装置を用い る内部加熱による溶解法 ${ }^{910)}$ も多く利用されている.

そこで本報告では，比較的多量の試料を迅速に溶解する ことを目的として，模擬廃棄物を溶融して調製した溶融固 化体試料に対して, 外部加熱のみによる酸分解法とマイク ロ波加熱を利用した酸分解法の適用を比較検討した。その 結果, マイクロ波加熱装置を用いる酸分解法を適用するこ とにより, 難溶解性の溶融固化体試料を効率的に溶液化す る方法を確立した。更に試料溶解法の妥当性確認のため に，入手可能な標準物質のうち，溶融固化体試料に比較的 性状の似ている高炉スラグに対して，マイクロ波加熱溶解 法を適用し，溶解操作における損失のないことを確認し た。
2 実験

\section{$2 \cdot 1$ 試料及び試薬}

模擬廃棄物の溶融固化体は, 商業用ポルトランドセメン トから調製したコンクリート $4.0 \mathrm{~kg}$ と $\mathrm{FeO}$ 試薬 $0.5 \mathrm{~kg}$ (99.9\%，シグマアルドリッチ製）を小型のプラズマ溶融 装置 ${ }^{11)}$ 用いて，アルミナるつぼ内で $\mathrm{N}_{2}$ プラズマにより $1650^{\circ} \mathrm{C}$ まで加熱して調製したものを使用した．溶融固化 体の一部を採取し，粉砕した後，ふるい分けし $75 \mu \mathrm{m}$ 以 下のものを溶解に用いた．高炬スラグは，日本鉄鋼認証標 準物質 JSS 900-1 を使用した。また，溶解用の試薬として， 硝酸 (60\%，小宗化学製，特級)，フッ化水素酸（46\%， 和光純薬製, 特級), 過塩素酸 ( $70 \%$, 小宗化学製, 特級), 硫酸 (97\%，和光純薬製，特級)，過酸化水素水 $(30 \%$, 和光純薬製, 特級), 蒸留水 (共栄製薬製) を使用した。

\section{$2 \cdot 2$ マイクロ波加熱装置}

マイクロ波加熱には，マイルストーンゼネラル製 ETOS900を使用した。試料容器はマイルストーンゼネラ ル製テフロン製高圧分解容器 HPS-100（内容量 $100 \mathrm{ml}$ ) を使用し，分解容器 6 個をモノブロック高圧ローターに セットし，同時に加熱した。

\section{$2 \cdot 3$ 測 定}

誘導結合プラズマ発光分光分析装置（ICP-AES）（島津 製 ICPS-7510）を用いて, 溶融固化体溶解液中の $\mathrm{Si}, \mathrm{Al}$, $\mathrm{Ca} ， \mathrm{Fe} ， \mathrm{Cr}$ 及び Na を検量線法により定量した。検量線 用溶液は，原子吸光分析用金属標準液（1 mg/ml）（和光 純薬製）を適宜希釈して調製した。ICP-AES の高周波出力

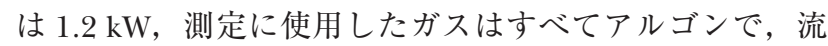
量はクーラントガス： $14.0 \mathrm{l} / \mathrm{min}$, プラズマガス： 1.2 1/min，キャリヤーガス: $0.7 \mathrm{l} / \mathrm{min}$ とした.

\section{3 結果と考察}

\section{$3 \cdot 1$ 溶融固化体の溶解}

\section{$3 \cdot 1 \cdot 1$ 外部加熱法の適用 はじめに難溶解性物質の}

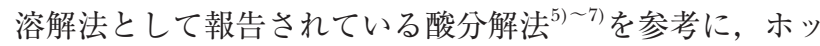
トプレートのみを用いた外部加熱法を検討した。適用した 溶解法を Fig. 1 に示す. 試料 $0.1 \mathrm{~g}$ をテフロンビーカーに 量り取り, 硝酸 $5 \mathrm{ml}$, フッ化水素酸 $5 \mathrm{ml}$ を加えて, ホッ トプレートで 2 時間加熱溶解したところ, 緑色の液体, 白色及び黒色の沈殿が混合した状態となった。これらを乾 固した後，硝酸 $5 \mathrm{ml}$, フッ化水素酸 $5 \mathrm{ml}$, 過塩素酸 $3 \mathrm{ml}$ を加えて 3 時間加熱したが，黒色の溶け残りがあった. 再度, 同量の硝酸, フッ化水素酸及び過塩素酸を加えて加 熱したが, 溶液化できなかったため, 乾固後, 硝酸 $2 \mathrm{ml}$, 過塩素酸 $2 \mathrm{ml}$ 及び硫酸 $3 \mathrm{ml}$ を添加して, 2 時間加熱溶解 
Table 1 Analytical results of a solidified product yielded by plasma melting treatment of simulated waste

\begin{tabular}{lcccccc}
\hline \multirow{2}{*}{ Methods } & \multicolumn{5}{c}{ Analytical results (mass\%, average value \pm standard deviation, $n=3$ ) } \\
\cline { 2 - 7 } & $\mathrm{SiO}_{2}$ & $\mathrm{Al}_{2} \mathrm{O}_{3}$ & $\mathrm{CaO}$ & $\mathrm{FeO}$ & $\mathrm{Na}_{2} \mathrm{O}$ & $\mathrm{Cr}_{2} \mathrm{O}_{3}$ \\
\hline External heating & & $8.9 \pm 0.2$ & $9.4 \pm 0.1$ & $13.7 \pm 0.2$ & $1.02 \pm 0.01$ & $0.63 \pm 0.01$ \\
Microwave heating & & $8.9 \pm 0.1$ & $10.4 \pm 0.3$ & $13.8 \pm 1.1$ & $1.06 \pm 0.03$ & $0.64 \pm 0.05$ \\
Alkali fusion & $62.6 \pm 0.4$ & & & & & \\
\hline
\end{tabular}

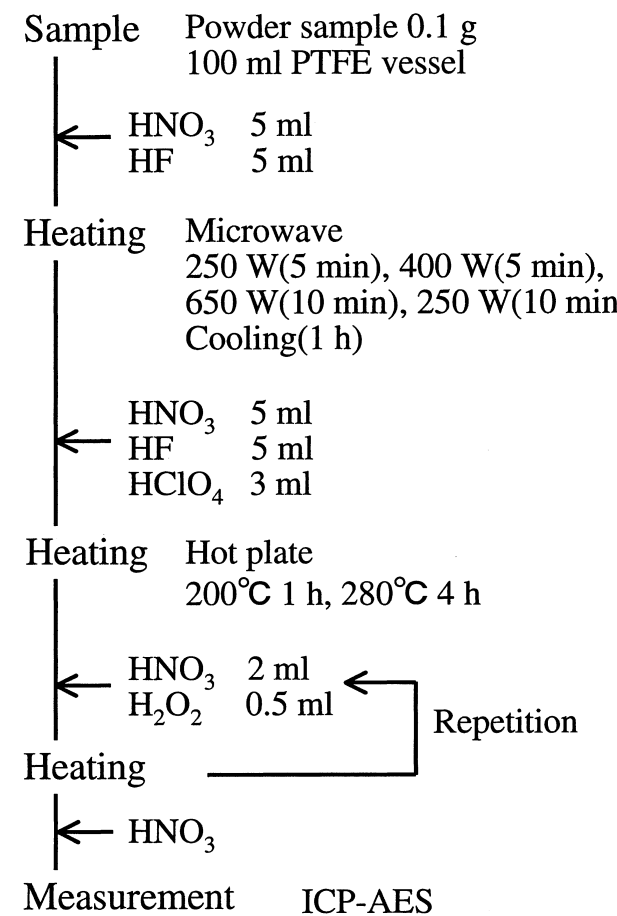

Fig. 2 Dissolution procedure with microwave heating devices for a solidified product yielded by plasma melting treatment

したわずかに白色の固形物が残った状態で，溶液を加熱 乾固した後, 硝酸 $2 \mathrm{ml}$ を加えて加熱乾固する操作を 2 回 繰り返し， $1 \mathrm{M}$ 硝酸溶液 $100 \mathrm{ml}$ に調製した。調製直後は わずかに白濁していたが，1 晚放置した後には完全に溶解 し, 透明な溶解液を得た。この溶解液を適宜希釈し, ICPAES 測定により, 溶融固化体の化学組成を求めた。金属 濃度を相当する酸化物の質量割合として表した結果を Table 1 の 1 行目に示す.ただし，Si はフッ化水素酸を添 加した酸分解法では揮発してしまうため, 別に炭酸ナトリ ウムを用いたアルカリ融解法により試料を溶解し, ICPAES により測定した結果を示している.

溶融固化体試料 $0.1 \mathrm{~g}$ の場合は, 沸点の高い硫酸を使用 することにより溶液化することができたが，1容器当たり の試料を $0.5 \sim 1.0 \mathrm{~g}$ まで増量し, 同様の溶解操作を行っ たところ, 硫酸塩が析出し, $500 \mathrm{ml}$ まで液量を増やして も溶解しなかった。金属の硫酸塩は溶解度の低いものが多
く，特に Table 1 に示したように溶融固化体には Ca が多 く含まれるため，溶液化できなかったものと考えられる. これ以上液量を増やすことは，その後の放射能測定及び化 学分離操作に対しては不都合であるため, 硫酸を使用しな い溶解法を検討する必要が生じた。

$3 \cdot 1 \cdot 2$ マイクロ波加熱法の適用硫酸を使用しない 溶解法として，マイクロ波加熱の利用を検討した。適用し た溶解法を Fig. 2 に示す. 試料 $0.1 \mathrm{~g}$ をテフロン製高圧分 解容器に量り取り, 硝酸 $5 \mathrm{ml}$, フッ化水素酸 $5 \mathrm{ml}$ を加え て密封後，急激な温度上昇を避けるためにマイクロ波の出 力を $250 \mathrm{~W}$ (5 分), $400 \mathrm{~W}$ (5 分), $650 \mathrm{~W}$ (10 分), 250 W（10 分）と変化させながら，合計 30 分間加熱し， 1 時 間放冷した。緑色の液体と白色の固形物に変化した内容物 をテフロンビーカーに移してホットプレート上で乾固した 後, 硝酸 $5 \mathrm{ml}$, フッ化水素酸 $5 \mathrm{ml}$, 過塩素酸 $3 \mathrm{ml}$ を加え て 1 時間加熱溶解したところ, 少量の蒸留水を加えると 透明になり，溶け残りのないことが確認できた。得られた 溶液はいったん乾固した後, 硝酸 $2 \mathrm{ml}$, 過酸化水素水 0.5 $\mathrm{ml}$ を加えて加熱乾固する操作を 2 回繰り返し， $1 \mathrm{M}$ 硝酸 溶液 $100 \mathrm{ml}$ に調製した。この溶解液を適宜希釈し，ICPAESにより測定した金属濃度を相当する酸化物の質量割 合として表した結果を Table 1 の 2 行目に示す。その結 果は，外部加熱法による結果とよく一致しており，硫酸を 添加しなくともマイクロ波加熱を利用することにより，難 溶解性の溶融固化体試料 $(0.1 \mathrm{~g})$ を溶解することができ た。

次に, 1 容器当たりの試料を $1.0 \mathrm{~g}$ に増量し, 同様にマ イクロ波加熱を利用した溶解操作を行ったところ，塩が析 出することなく $100 \mathrm{ml}$ 溶液に調製することができた。こ の結果, $\mathrm{g}$ 単位の溶融固化体試料を溶解するには, マイク ロ波加熱の適用が有効であることが分かった。

\section{$3 \cdot 2$ 高炉スラグの溶解}

高炉スラグは，銑鉄を製造する際に，溶融された鉄鉱石 の鉄以外の成分が，副原料である石灰石やコークス中の灰 分ととも分離回収されたもので，鉄の含有量は少ないが, 標準物質として入手可能な試料のうち, 溶融固化体と比較 的性状が似ているため, 溶解操作における損失のないこと を確認するために使用した。この高炉スラグに対して， 
Table 2 Analytical results of Blast Furnace slag (JSS 900-1)

\begin{tabular}{|c|c|c|c|c|c|c|}
\hline \multirow{2}{*}{ Methods } & \multicolumn{6}{|c|}{ Analytical results (mass $\%$, average value \pm standard deviation, $n=3$ ) } \\
\hline & $\mathrm{SiO}_{2}$ & $\mathrm{Al}_{2} \mathrm{O}_{3}$ & $\mathrm{CaO}$ & $\mathrm{Fe}$ & $\mathrm{Na}$ & $\mathrm{Cr}$ \\
\hline External heating & & $12.9 \pm 0.2$ & $43.5 \pm 0.7$ & $0.24 \pm 0.01$ & $0.22 \pm 0.02$ & $<0.05$ \\
\hline Microwave heating & & $12.9 \pm 0.4$ & $42.0 \pm 2.5$ & $0.34 \pm 0.02$ & $0.19 \pm 0.03$ & $<0.05$ \\
\hline Alkali fusion & $33.5 \pm 0.9$ & & & & & \\
\hline Certified value & $32.9 \pm 0.1$ & $13.1 \pm 0.1$ & $43.6 \pm 0.1$ & $0.24 \pm 0.01$ & $0.18 \pm 0.01$ & $0.002^{a)}$ \\
\hline
\end{tabular}

a) Non-certified value

$3 \cdot 1 \cdot 1$ に示したホットプレートのみによる外部加熱法及び $3 \cdot 1 \cdot 2$ に示したマイクロ波加熱法を適用し，それぞれの方 法で調製した溶解液を ICP-AESにより測定し, 化学組成 を求めた．認証值の表記に合わせて金属及び相当する酸化 物の質量割合として表した結果を Table 2 に示す。主要 な成分については，いずれの溶解法を用いても認証值とよ く一致しており, 溶解操作における損失のないことが確認 できた。ここで，マイクロ波加熱法による $\mathrm{Fe}$ の分析值が 認証值より若干大きな值となっているのは，溶融固化体試 料に対して用いた高圧分解容器を高炬スラグの溶解に使用 したことが原因と推測される. 高炉スラグの化学組成は溶 融固化体試料と比較的類似しているが, $\mathrm{Fe}$ の含有量が非 常に少ないために，Feの測定值が影響を受けたものと考 えられる. 高圧分解容器は比較的高価であるため, 繰り返 して使用する場合が多いと考えられるが, 繰り返して使用 する場合には化学組成の類似した試料にのみ用いることが 望ましい。

以上の結果から，溶融固化体試料に対する迅速溶解法と して, マイクロ波加熱装置を用いる溶解法を確立すること ができた。ホットプレートのみによる外部加熱法では，1 容器当たり溶液化可能な溶融固化体試料は $0.1 \mathrm{~g}$ 程度であ ったが，マイクロ波加熱法を適用することにより，試料量 を $1.0 \mathrm{~g}$ まで増量しても溶液化することができた，g単位 で試料を溶液化する必要のある溶融固化体試料に対してマ イクロ波加熱法を適用することにより, 溶解操作の所要時
間を大幅に短縮することができた。

\section{文献}

1) H. Higuchi, M. Sato, N. Nakashio, M. Okoshi, M. Tanaka: "Advanced volume reduction program for LLW at JAERI", Proc. Int. Conf. Safewaste 2000, Montpellier Corum, France, Vol. 1, p. 314 (2000).

2) 亀尾 裕, 原賀智子, 中塩信行, 星严紀子, 中島 幹雄：日本原子力学会和文論文誌, 3, 354 (2004).

3) 坂井章浩, 吉森道郎, 阿部昌義: “研究所等廃棄物 の埋設処分における安全評価上重要核種の選定 (そ の 1) 一主要放射性廃棄物発生施設別の核種組成比 の評価”, JAERI-Tech 2000-012, 日本原子力研究所, (2000).

4) 浅井志保，坂井章浩，吉森道郎，木原伸二: “RI·研 究所等廃棄物の埋設処分における安全評価上重要核 種の選定 (その 2) 一原子炉施設および照射後試験 施設から発生した廃棄物の核種分析手法の検討”, JAERI-Tech 2003-071, 日本原子力研究所, (2003).

5) 桂＼cjkstart敬：ぶんせき (Bunseki), 1979, 648.

6) 伊藤光雄，小原和弘，樋田行雄，鈴木大輔，郡司 勝文，加藤金治，渡部和男：“依頼分析及びガラス 工作業務報告書 (平成 12 年度)”, JAERI-Review 2001-045, 日本原子力研究所, (2002).

7) 松本 健: ぶんせき (Bunseki), 2002, 60.

8) 内田哲男：ぶんせき (Bunseki), 1986, 9.

9) 小島 功: ぶんせき (Bunseki), 1992, 14 .

10) K. J. Lamble, S. J. Hill : Analyst, 123, 103R (1998).

11) M. Nakashima, T. Fukui, N. Nakashio, M. Isobe, A. Ohtake, T. Wakui, T. Hirabayashi: J. Nucl. Sci. Technol., 39, 687 (2002). 